\title{
FORMATION OF Ni-Ti INTERMETALLICS DURING REACTIVE SINTERING AT $800-900{ }^{\circ} \mathrm{C}$
}

\author{
OBLIKOVANJE NiTi INTERMETALNIH ZLITIN MED \\ REAKTIVNIM SINTRANJEM PRI $800-900{ }^{\circ} \mathrm{C}$
}

\author{
Pavel Novák ${ }^{1}$, Vladimír Vojtěch ${ }^{1}$, Zuzana Pecenová1, Filip Průša ${ }^{1}$, Petr Pokorný ${ }^{1}$, \\ Davy Deduytsche ${ }^{2}$, Christophe Detavernier ${ }^{2}$, Adriana Bernatiková1, \\ Pavel Salvetr ${ }^{1}$, Anna Knaislová ${ }^{1}$, Kateřina Nová ${ }^{1}$, Lucyna Jaworska ${ }^{3}$ \\ ${ }^{1}$ University of Chemistry and Technology, Department of Metals and Corrosion Engineering, Technická 5, \\ 16628 Prague 6, Czech Republic \\ ${ }^{2}$ Ghent University, Department of Solid State Sciences, Krijgslaan 281, S1 9000 Gent, Belgium \\ ${ }^{3}$ Institute of Advanced Manufacturing Technology, 37a Wroclawska St., 30-011 Krakow, Poland \\ panovak@vscht.cz \\ Prejem rokopisa - received: 2016-08-17; sprejem za objavo - accepted for publication: 2016-11-16
}

doi:10.17222/mit.2016.257

\begin{abstract}
In this work the formation of intermetallics in the Ni-Ti system by reactive sintering at $800-900{ }^{\circ} \mathrm{C}$ was studied. The mechanism and kinetics of the reactions, which led to Ni-Ti phases, were determined by thermal analysis, in-situ XRD and the application of an experimental model consisting of nickel-plated titanium. It was found that the formation of Ni-Ti phases below the transformation temperature of titanium is controlled by diffusion. Above this temperature, the reactions switch to the rapid Self-propagating High-temperature Synthesis (SHS) mode.

Keywords: reactive sintering, powder metallurgy, NiTi
\end{abstract}

V delu je bil raziskan nastanek intermetalnih zlitin v sistemu NiTi pri reaktivnem sintranju na $800-900{ }^{\circ} \mathrm{C}$. S termično analizo, XRD-in situ analizo in uporabo eksperimentalnega modela, nikljanega s titanom, sta bila določena mehanizem in kinetika reakcij, ki sta vodila k NiTi fazam. Ugotovljeno je bilo, da je tvorba NiTI faze pod transformacijsko temperaturo titana, nadzorovana $z$ difuzijo. Nad to temperaturo se reakcije spremenijo na hitro rastoči temperaturno -sintezni način (SHS).

Ključne besede: reaktivno sintranje, metalurgija prahov, NiTi

\section{INTRODUCTION}

The Ni-Ti alloy called nitinol, in approximately equimolar proportions, is the most widely known shapememory alloy. The shape-memory effect in this alloy is connected with the transformation between high-temperature cubic austenite and low-temperature monoclinic martensite..$^{1,2}$ For the practical application of these alloys, superelasticity is very important. This phenomenon occurs when the NiTi alloy is deformed slightly above the martensite $\rightarrow$ austenite transformation temperature. Deformation induces the formation of the martensite phase, which is continuously transformed to austenite during unloading. Due to this phenomenon, this alloy behaves like an enormously elastic material. ${ }^{1,2}$ In addition, the NiTi alloy is also a corrosion-resistant material. ${ }^{3}$ Due to its exceptional properties, the NiTi alloy is applied in both medical (dental implants, stents, scaffolds) $)^{4,5}$ and technical applications (actuators, robotics, etc.). ${ }^{6-8}$

The most commonly applied techniques in the industrial production of nitinol alloy are melting metallurgy processes - vacuum induction melting (VIM) and vacuum arc remelting (VAR). ${ }^{9,10}$ In the VIM of Ti-containing alloys there is a serious danger of a strong contamination of the melt due to the high reactivity of molten titanium. ${ }^{11}$ The VAR technique makes it possible to prepare alloys of higher purity, but there is a problem with homogeneity. To obtain a sufficiently homogenous product, the VAR process has to be repeated even more than 4 times. ${ }^{10}$ This implies that it is costly and relatively problematic to obtain a NiTi shape-memory alloy. If a simple production technology would be developed, the NiTi alloy could be more frequently applied, not only in specific areas requiring the shape-memory effect, but also in other technical branches as a corrosion-resistant alloy. It will be beneficial for European economy, because this alloy does not contain any elements listed as critical raw materials. ${ }^{12}$

A promising alternative to melting metallurgy production routes is powder metallurgy (PM). A simple non-conventional PM production technology is reactive sintering. In general, the reactive sintering is a densification process, where initial components in powder form are transformed to a compact product via thermally-activated chemical reactions. ${ }^{13}$ These reactions are mostly exothermic when intermetallics are formed. The route from powders to the compact usually contains powder blending, cold pressing and sintering. ${ }^{13,14}$ When pure powders and an efficient protective atmosphere are 
applied, a high-purity product is obtained due to the limited contact of the compressed reaction mixture with the crucible or support during the process.

The reactive sintering process of many intermetallics, including the Ni-Ti alloy, proceeds in two stages: a lower-temperature diffusional stage and a rapid hightemperature process called Self-propagating High-temperature Synthesis (SHS). ${ }^{13-15}$

In the case of the reactive sintering of NiTi alloy, the following mechanism is proposed in the literature. During heating to $900{ }^{\circ} \mathrm{C}$, the slow diffusional formation of three intermetallics $\left(\mathrm{Ti}_{2} \mathrm{Ni}, \mathrm{NiTi}\right.$ and $\left.\mathrm{Ni}_{3} \mathrm{Ti}\right)$ proceeds. In our previous paper we found that traces of the $\mathrm{Ti}_{2} \mathrm{Ni}$ phase start to form already at $471{ }^{\circ} \mathrm{C}$, being followed by $\mathrm{NiTi}$ and $\mathrm{Ni}_{3} \mathrm{Ti}$ at $632{ }^{\circ} \mathrm{C} .{ }^{16}$ The transformation of $\alpha$-Ti to $\beta$-Ti takes place as the temperature increases and after that the $\beta$-Ti rapidly saturates with nickel. When the temperature exceeds $942{ }^{\circ} \mathrm{C}$, a liquid phase is formed from the solid solution of nickel in $\beta$-Ti by eutectic transformation and thus ignites the SHS reaction. ${ }^{15}$ However, in our previous paper about the optimization of the conditions for the reaction synthesis of the NiTi shape memory alloy the structure corresponding to the SHS reaction was observed already after heating to $900{ }^{\circ} \mathrm{C}$, being very similar to the material processed at $1100{ }^{\circ} \mathrm{C} .{ }^{17}$

This paper aims to explain how it is possible to initiate the SHS reaction in NiTi alloy at $900{ }^{\circ} \mathrm{C}$. To prove it, the mechanism and kinetics of the Ni+Ti reactions were studied by thermal analysis, in-situ XRD analysis and an experimental model.

\section{MATERIALS AND METHODS}

As mentioned above, the structure appearing to result from SHS reaction was observed in the NiTi alloy already at $900{ }^{\circ} \mathrm{C}$ using a heating rate of approximately $300{ }^{\circ} \mathrm{C} / \mathrm{min},{ }^{17}$ even though other references state that the SHS reaction is triggered by the melt formation by eutectic reaction at $942{ }^{\circ} \mathrm{C}$. To prove the possibility to initiate the SHS reaction under these conditions and to describe the reaction mechanism, the following steps were carried out:

- Thermal analysis during heating from room temperature to approximately $1200{ }^{\circ} \mathrm{C}$ with the heating rate of approximately $300{ }^{\circ} \mathrm{C} / \mathrm{min}$. The heating rate was the same as in our previous paper, where the structure corresponding to the SHS reaction was observed after the process at $900{ }^{\circ} \mathrm{C} .{ }^{17}$

- In-situ XRD analysis during heating from the laboratory temperature to $900^{\circ} \mathrm{C}$ with the heating rate of $60{ }^{\circ} \mathrm{C} / \mathrm{min}$. The heating rate was limited by the capabilities of the device.

- Description of mechanism and kinetics of the Ni-Ti phases' formation at $800{ }^{\circ} \mathrm{C}$ and $900{ }^{\circ} \mathrm{C}$ using an experimental model.
- Reactive sintering of Ni-Ti samples at $800{ }^{\circ} \mathrm{C}$ and $900{ }^{\circ} \mathrm{C}$ with the heating rate of $300{ }^{\circ} \mathrm{C} / \mathrm{min}$.

Experimental material for thermal analysis and in-situ XRD was prepared by blending of nickel powder (particle size < $150 \mu \mathrm{m},>99.99 \%$ purity, supplied by Aldrich) and titanium powder (particle size $<44 \mu \mathrm{m},>$ $99.5 \%$ purity, supplied by Alfa Aesar). Green bodies with a cylindrical shape of $10 \mathrm{~mm}$ in diameter and approximately $5 \mathrm{~mm}$ in height were prepared by uniaxial cold pressing of the powder blends under a pressure of $630 \mathrm{MPa}$ using LabTest 5.250SP1-VM universal loading machine.

Thermal analysis was carried out during heating in the induction furnace from room temperature to $900{ }^{\circ} \mathrm{C}$ with the heating rate of approximately $300{ }^{\circ} \mathrm{C} / \mathrm{min}$. An optical pyrometer (Optris P20 2M) was used to record the temperature profile of the reaction.

In-situ XRD analysis $\left(\mathrm{Cu}-K_{\alpha}\right.$ radiation) was carried out during heating from laboratory temperature to $900{ }^{\circ} \mathrm{C}$ in a helium atmosphere with a heating rate of $60{ }^{\circ} \mathrm{C} / \mathrm{min}$.

An experimental model was established and successfully applied in our previous works in the $\mathrm{Fe}-\mathrm{Al}$, Fe-Al-Si and Ti-Al-Si systems. ${ }^{18,19}$ In the mentioned papers, the experimental model consisted of an iron or titanium sample submerged in molten aluminium or Al-Si alloy. The aim of these experiments was to describe the kinetics of the formation of intermetallics in these particular alloys systems, because directly in reactive sintering process it is not possible. In the present work a model (Ni-Ti diffusion couple) consisting of a titanium bulk sample coated with nickel was applied. The nickel-plated titanium simulates the interaction between the compressed titanium and nickel powder particles. The galvanic nickel plating was carried out at $60{ }^{\circ} \mathrm{C}$ in a Watts's bath containing $300 \mathrm{~g} / \mathrm{L} \mathrm{NiSO}_{4} \cdot 7 \mathrm{H}_{2} \mathrm{O}$, $40 \mathrm{~g} / \mathrm{L} \mathrm{NiCl}{ }_{2}$ and $40 \mathrm{~g} / \mathrm{L} \mathrm{H}_{3} \mathrm{BO}_{3}$ using a current density of $10 \mathrm{~A} / \mathrm{m}$ to the final thickness of approximately $20 \mu \mathrm{m}$. Before galvanic plating, titanium samples were sandblasted with alumina for $10 \mathrm{~min}$, pickled in $35 \% \mathrm{HCl}$ at $60{ }^{\circ} \mathrm{C}$ for $12 \mathrm{~min}$ and activated in $35 \% \mathrm{HCl}$ at $20{ }^{\circ} \mathrm{C}$ for $15 \mathrm{~s}$. The coated samples were annealed for 30-180 min in evacuated and sealed silica ampoules at $800{ }^{\circ} \mathrm{C}$. At $900{ }^{\circ} \mathrm{C}$, the experiment was stopped after $120 \mathrm{~min}$, because the whole thickness of the nickel coating reacted to form Ni-Ti phases. The heating rate during the experiments was approximately $300{ }^{\circ} \mathrm{C} / \mathrm{min}$. The phase composition of the obtained multilayer systems was identified by the X-ray diffraction (XRD) method using PANalytical X'Pert Pro diffractometer $\left(\mathrm{Cu}-K_{\alpha}\right.$ radiation). PANalytical X'Pert HighScore Plus software with the PDF-2 database was used to process and to evaluate the XRD patterns. The microstructure of intermetallics' layers was examined with a TESCAN VEGA 3 scanning electron microscope equipped with OXFORD Instruments X-max EDS SDD $20 \mathrm{~mm}^{2}$ detector (SEM-EDS). Samples were mechanically ground, polished and etched using modified Kroll's reagent $\left(10 \mathrm{~mL} \mathrm{HF,} 40 \mathrm{~mL} \mathrm{HNO}_{3}\right.$ 
and $50 \mathrm{H}_{2} \mathrm{O}$ ) before the microstructure observation. Image analysis was carried out by the means of ImageJ software in order to determine the thickness of the intermetallics' layers. A process controlling the formation of intermetallics was determined by fitting the layer thickness with a parabolic growth equation. When a process is controlled by diffusion of species through a reaction product, it is generally described by the parabolic law, written as Equation (1):

$$
d=\sqrt{k_{\mathrm{p}} \cdot t}
$$

where $d$ is the layer thickness $(\mu \mathrm{m})$ and $t$ represents the annealing duration (s). ${ }^{20}$

\section{RESULTS AND DISCUSSION}

The temperature profile during heating of the compressed powder mixture of nickel and titanium was recorded using an optical pyrometer. During heating in an induction furnace by the rate of nearly $300{ }^{\circ} \mathrm{C} / \mathrm{min}$, the temperature increased almost linearly up to approximately $880{ }^{\circ} \mathrm{C}$ (Figure 1). After that, the increase of the slope, i.e., the heating rate, can be observed. This increase can be probably be attributed to the initiation of the strongly exothermal SHS reaction. This temperature corresponds well with the transformation of titanium from hexagonal (hcp) structure to cubic (bcc) one. ${ }^{21}$ After achieving approximately $940{ }^{\circ} \mathrm{C}$, the slope of the curve increases even more rapidly, probably due to the formation of a liquid phase by the eutectic transformation in the Ni-Ti system $\left(942{ }^{\circ} \mathrm{C}\right) .{ }^{21}$ The liquid medium supports the SHS reaction by increasing the diffusion rate of the reactants. The maximum temperature achieved by the reactions was $1137^{\circ} \mathrm{C}$. This indicates that the sample was partially molten due to eutectic

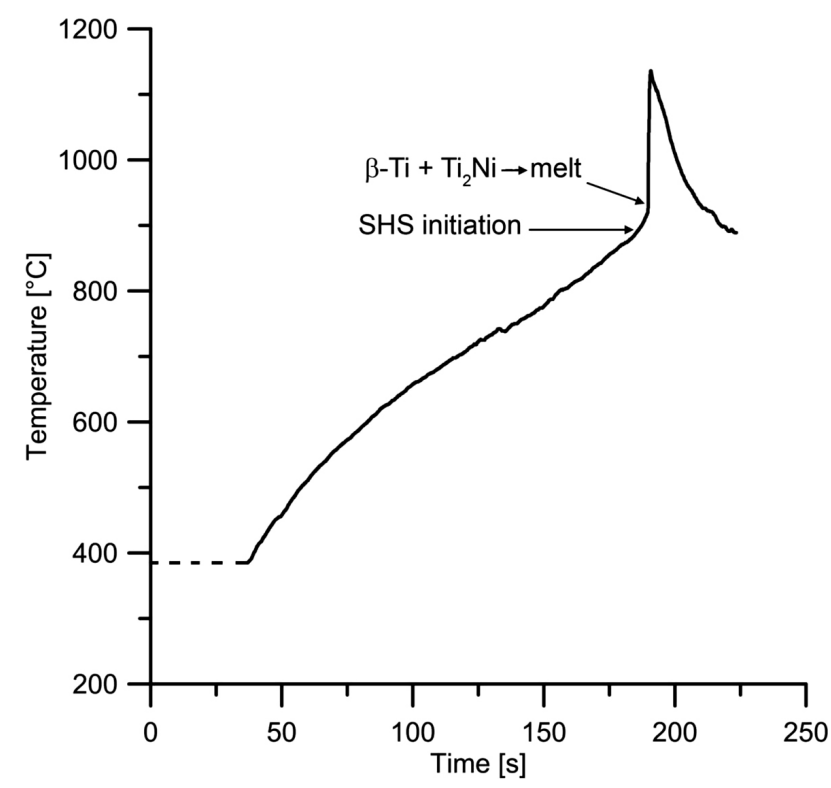

Figure 1: Heating curve of $\mathrm{Ni}-\mathrm{Ti}$ compressed powder mixture (heating rate of approx. $300{ }^{\circ} \mathrm{C} \mathrm{min}^{-1}$, recorded by optical pyrometer) reactions at $942{ }^{\circ} \mathrm{C}$ and $1118{ }^{\circ} \mathrm{C}$, but did not exceed the melting point of the NiTi phase $\left(1310{ }^{\circ} \mathrm{C}\right) .{ }^{21}$ It can be expected that the temperature at the reaction front can be even higher, but the heat is quickly transferred to the rest of the sample and therefore the overall temperature of the sample is lower.

The in-situ XRD analysis during heating of the compressed powder mixture from the room temperature to $900{ }^{\circ} \mathrm{C}$ with a rate of $60{ }^{\circ} \mathrm{C} / \mathrm{min}$ (Figure 2) shows the continuous shift of the diffraction lines of nickel and titanium to lower angles with increasing temperature. This phenomenon is caused by the thermal expansion of the powders. In addition, the phase transformation of hexagonal $\alpha$-Ti to cubic $\beta$-Ti can be observed around the temperature expected according to the $\mathrm{Ni}$-Ti phase diagram $\left(882{ }^{\circ} \mathrm{C}\right) .{ }^{21} \mathrm{In}$ addition to this phase transformation, the weak diffraction lines of the $\mathrm{Ti}_{2} \mathrm{Ni}$ (cubic structure $\mathrm{Fd} \overline{3} \mathrm{~m}$ ) ${ }^{21}$ and NiTi (austenite, cubic structure $\operatorname{Pm} \overline{3} \mathrm{~m})^{21}$ phases start to be visible at approximately $750{ }^{\circ} \mathrm{C}$. The intensity of the lines of the $\mathrm{Ti}_{2} \mathrm{Ni}$ phase increase very rapidly, when a temperature of approximately $880{ }^{\circ} \mathrm{C}$ is achieved (Figure 2). This increase is immediately followed by the rapid formation of $\mathrm{NiTi}$ (austenite, cubic structure $\mathrm{Pm} \overline{3} \mathrm{~m})^{21}$ and $\mathrm{Ni}_{3} \mathrm{Ti}$ (hexagonal $\left.\mathrm{P}_{3} / \mathrm{mmc}\right)^{21}$. It implies that the SHS reaction between nickel and titanium is initiated by the transformation of titanium to its cubic allotropic modification. It forms the $\mathrm{Ti}_{2} \mathrm{Ni}$ phase, which then reacts with nickel and/or the $\mathrm{Ni}_{3} \mathrm{Ti}$ phase to form NiTi (austenite). The same phases' formation sequence was also observed for the diffusion stage of the reactive sintering process during long-term annealing at $500-650{ }^{\circ} \mathrm{C}$. It implies that $\mathrm{Ti}_{2} \mathrm{Ni}$ forms preferentially and it cannot be avoided in both low-temperature diffusion process, as well as during SHS mode.

To be able to describe the kinetics of the formation of intermetallics, the experimental model simulating the interaction between compressed nickel and titanium particles was applied. The model consisted of a bulk titanium sample covered by a nickel layer of approximately $20 \mu \mathrm{m}$ in thickness. The model samples were

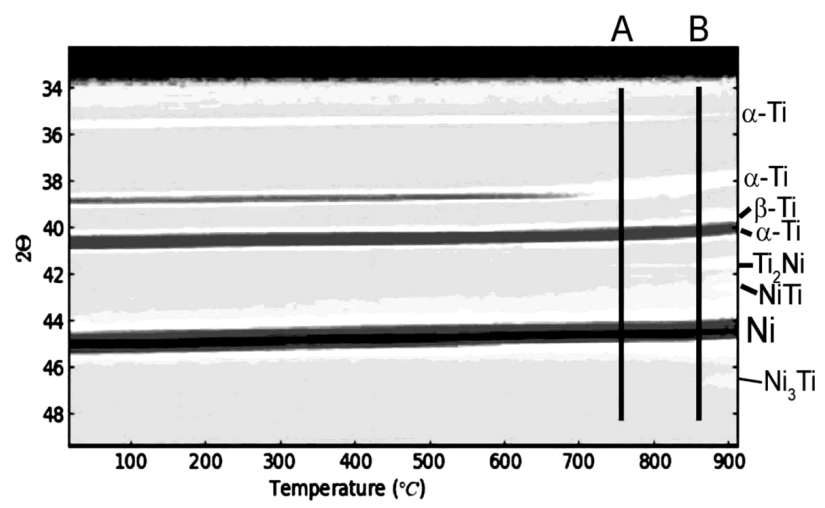

Figure 2: Variation of XRD intensities of NiTi46 (in mass fractions, $(w / \%)$ ) compressed powder mixture during heating from room temperature to $900{ }^{\circ} \mathrm{C}$ (heating rate of $60{ }^{\circ} \mathrm{C} \mathrm{min}^{-1}$ ) 


\section{MATERIALI IN TEHNOLOGIJE/MATERIALS AND TECHNOLOGY (1967-2017) - 50 LET/50 YEARS}

P. NOVÁK et al.: FORMATION OF Ni-Ti INTERMETALLICS DURING REACTIVE SINTERING AT 800-900 ${ }^{\circ} \mathrm{C}$
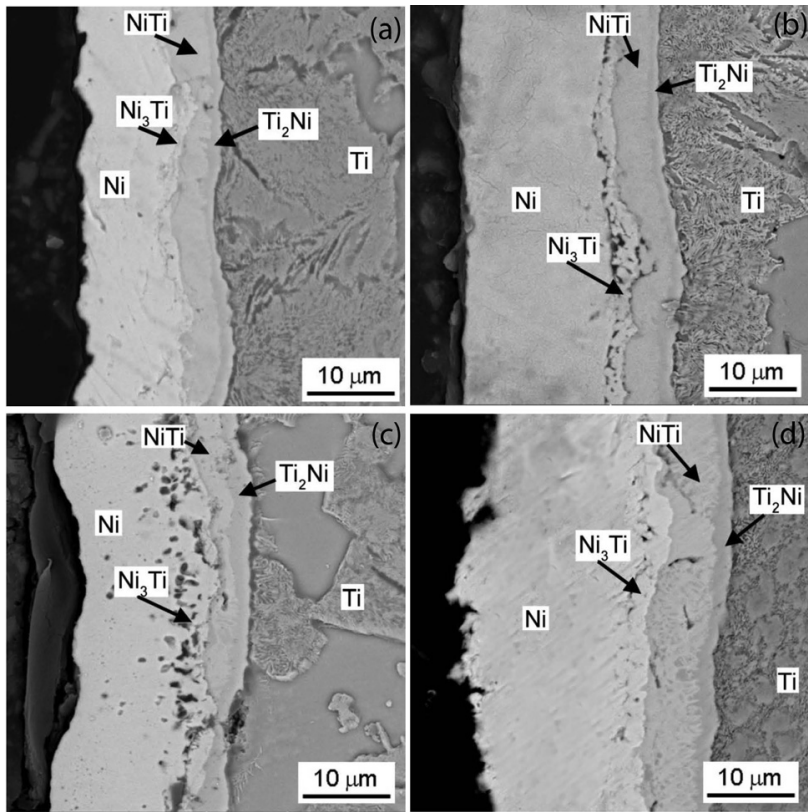

Figure 3: Microstructure of Ni-Ti model samples annealed at $800{ }^{\circ} \mathrm{C}$ for: a) $30 \mathrm{~min}$, b) $60 \mathrm{~min}$, c) $120 \mathrm{~min}$ and d) $180 \mathrm{~min}$

annealed at $800{ }^{\circ} \mathrm{C}$ and $900{ }^{\circ} \mathrm{C}$ and the thickness of formed layers of intermetallics was measured to describe the difference between in the mechanism and kinetics of the $\mathrm{Ni}+\mathrm{Ti}$ reactions below and above the $\alpha \rightarrow \beta$ transformation temperature in titanium. During annealing at $800{ }^{\circ} \mathrm{C}$, the layers of $\mathrm{Ti}_{2} \mathrm{Ni}, \mathrm{NiTi}$ and $\mathrm{Ni}_{3} \mathrm{Ti}$ are formed between the titanium and nickel coating (Figure 3a to 3d). The presence of these phases was confirmed by the XRD (Figure 4) and local EDS analysis (Table 1). While the XRD analysis revealed all present layers on the sample, the EDS analysis was used to identify the sequence of the layers between the reacting titanium and nickel. The dependences of the thickness of the $\mathrm{Ti}_{2} \mathrm{Ni}$

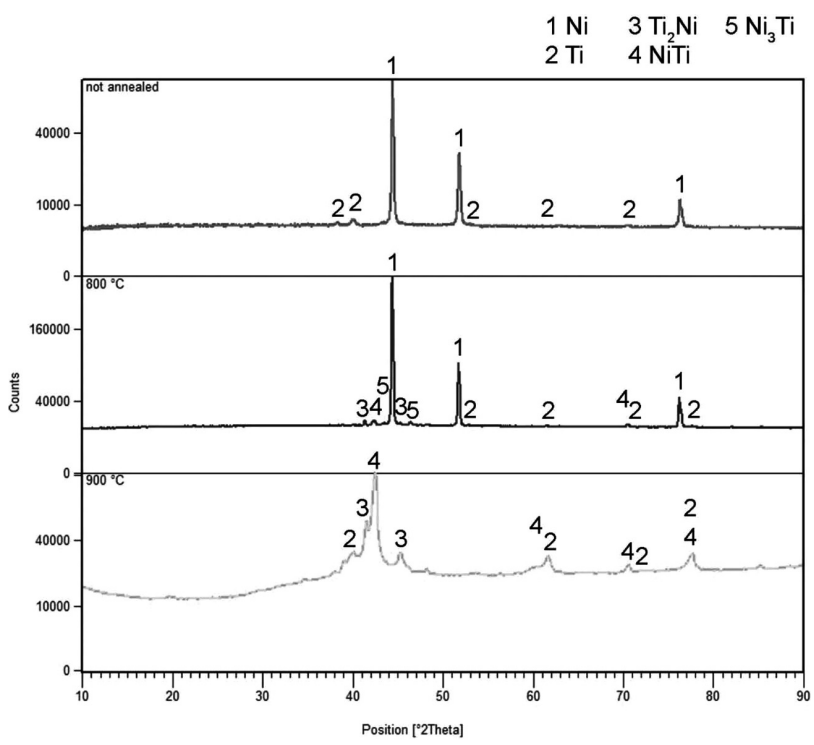

Figure 4: XRD patterns of model samples annealed at $800{ }^{\circ} \mathrm{C}$ and $900{ }^{\circ} \mathrm{C}$ and NiTi layers on the process duration exhibit the parabolic shape (Figure 5). The calculated parabolic rate constants for all the samples indicate that the growth of these layers slightly slows down with the process duration (Table 2). The layer of $\mathrm{Ni}_{3} \mathrm{Ti}$ (hexagonal $\left.\mathrm{P}_{3} / \mathrm{mmc}\right)^{21}$ phase starts to grow after $60 \mathrm{~min}$ of annealing and then it follows the parabolic law. The formation of the $\mathrm{Ni}_{3} \mathrm{Ti}$ phase is probably the reason why the growth of the $\mathrm{NiTi}$ and $\mathrm{Ti}_{2} \mathrm{Ni}$ layers decelerates during longer annealing. As the $\mathrm{Ni}_{3} \mathrm{Ti}$ phase grows, $\mathrm{NiTi}$ and/or $\mathrm{Ti}_{2} \mathrm{Ni}$ are consumed, as well as nickel. The results confirm that during the diffusion stage, the process starts with the formation of $\mathrm{Ti}_{2} \mathrm{Ni}$ and $\mathrm{NiTi}$ layers, followed by $\mathrm{Ni}_{3} \mathrm{Ti}$ after longer annealing duration. Almost the same shape of the kinetic curves was also observed during annealing at $650{ }^{\circ} \mathrm{C}$ in our previous paper, where the formation of $\mathrm{Ni}-\mathrm{Ti}$ intermetallics was studied during long-term annealing at 500-650 ${ }^{\circ} \mathrm{C} .{ }^{16}$

Table 1: Chemical composition (EDS) of layers observed after annealing of model samples at $800{ }^{\circ} \mathrm{C}$ for $120 \mathrm{~min}$

\begin{tabular}{|c|c|c|}
\hline \multirow{2}{*}{ Phase } & \multicolumn{2}{|c|}{ Content (in amount fractions, $(a / \%)$ ) } \\
\cline { 2 - 3 } & $\mathrm{Ti}$ & $\mathrm{Ni}$ \\
\hline $\mathrm{Ni}$ & $4.0 \pm 0.2$ & $96.0 \pm 0.2$ \\
\hline $\mathrm{Ti}{ }_{2} \mathrm{Ni}$ & $65.7 \pm 0.6$ & $34.3 \pm 0.6$ \\
\hline $\mathrm{NiTi}$ & $51.4 \pm 0.4$ & $48.6 \pm 0.4$ \\
\hline $\mathrm{Ni}_{3} \mathrm{Ti}$ & $27.9 \pm 1.8$ & $72.1 \pm 1.8$ \\
\hline $\mathrm{Ti}$ & $98.4 \pm 0.2$ & $1.6 \pm 0.2$ \\
\hline
\end{tabular}

Annealing at $900{ }^{\circ} \mathrm{C}$ leads to the layers of $\mathrm{Ti}_{2} \mathrm{Ni}$ and NiTi (Table 3, Figure 4), which grow slightly more rapidly up to $60 \mathrm{~min}$ (Figure 6a) than at $800{ }^{\circ} \mathrm{C}$ (Figure 5). However, the thickness of the NiTi phase layer is very non-uniform. After $60 \mathrm{~min}$, the thick layer of $\mathrm{Ni}_{3} \mathrm{Ti}$ (hexagonal $\mathrm{P}_{3} / \mathrm{mmc}$ ) phase arises in the structure. The

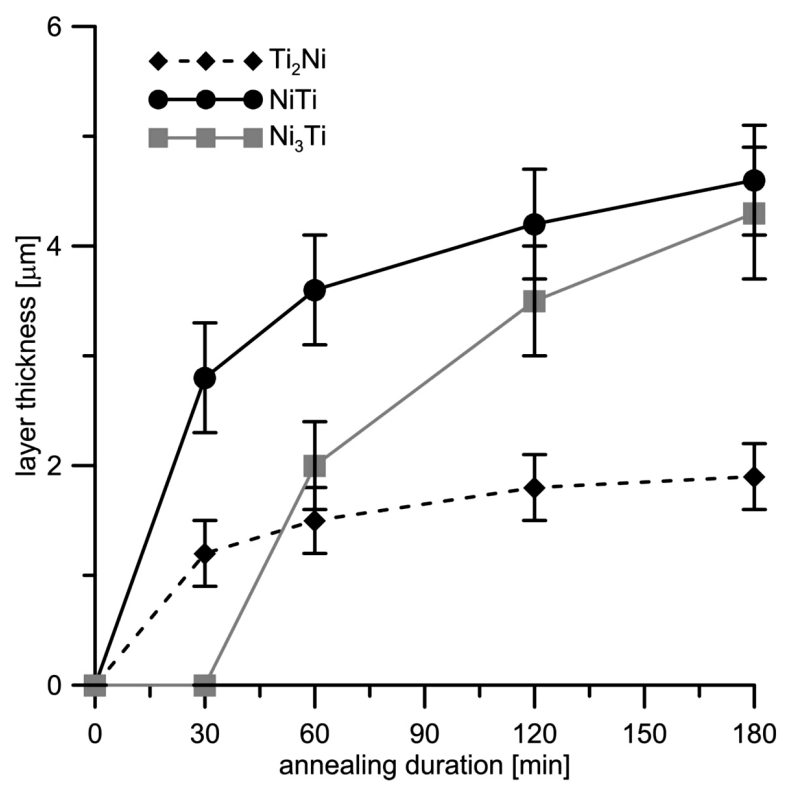

Figure 5: $\mathrm{NiTi}, \mathrm{Ti}_{2} \mathrm{Ni}$ and $\mathrm{Ni}_{3} \mathrm{Ti}$ layer thickness on model samples vs. duration of annealing at $800{ }^{\circ} \mathrm{C}$ 
Table 2: Parabolic rate constant of the formation of $\mathrm{Ti}_{2} \mathrm{Ni}$, NiTi and $\mathrm{Ni}_{3} \mathrm{Ti}$ layer vs. annealing duration at $800{ }^{\circ} \mathrm{C}$

\begin{tabular}{|c|c|c|c|}
\hline \multirow{2}{*}{$\begin{array}{c}\text { Annealing } \\
\text { duration (min) }\end{array}$} & \multicolumn{3}{|c|}{$\begin{array}{c}\text { Parabolic rate constant of the growth of } \\
\text { layers }\left(\times 10^{-4} \mu \mathrm{m} \mathrm{s}^{-1}\right)\end{array}$} \\
\cline { 2 - 4 } & $\mathrm{Ti}_{2} \mathrm{Ni}$ & $\mathrm{NiTi}$ & $\mathrm{Ni}_{3} \mathrm{Ti}$ \\
\hline 30 & 8.0 & 43.6 & 0 \\
\hline 60 & 6.3 & 36.0 & 11.1 \\
\hline 120 & 4.5 & 24.5 & 17.0 \\
\hline 180 & 3.3 & 19.6 & 17.1 \\
\hline
\end{tabular}

Table 3: Chemical composition (EDS) of layers observed after annealing of model samples at $900{ }^{\circ} \mathrm{C}$ for $120 \mathrm{~min}$

\begin{tabular}{|c|c|c|}
\hline \multirow{2}{*}{ Phase } & \multicolumn{2}{|c|}{ Content (in amount fractions, $(a / \%)$ ) } \\
\cline { 2 - 3 } & $\mathrm{Ti}$ & $\mathrm{Ni}$ \\
\hline $\mathrm{Ti}_{2} \mathrm{Ni}$ & $66.8 \pm 0.5$ & $33.2 \pm 0.5$ \\
\hline $\mathrm{NiTi}$ & $53.2 \pm 0.9$ & $46.8 \pm 0.9$ \\
\hline $\mathrm{Ti}$ & $97.8 \pm 0.3$ & $2.2 \pm 0.3$ \\
\hline
\end{tabular}
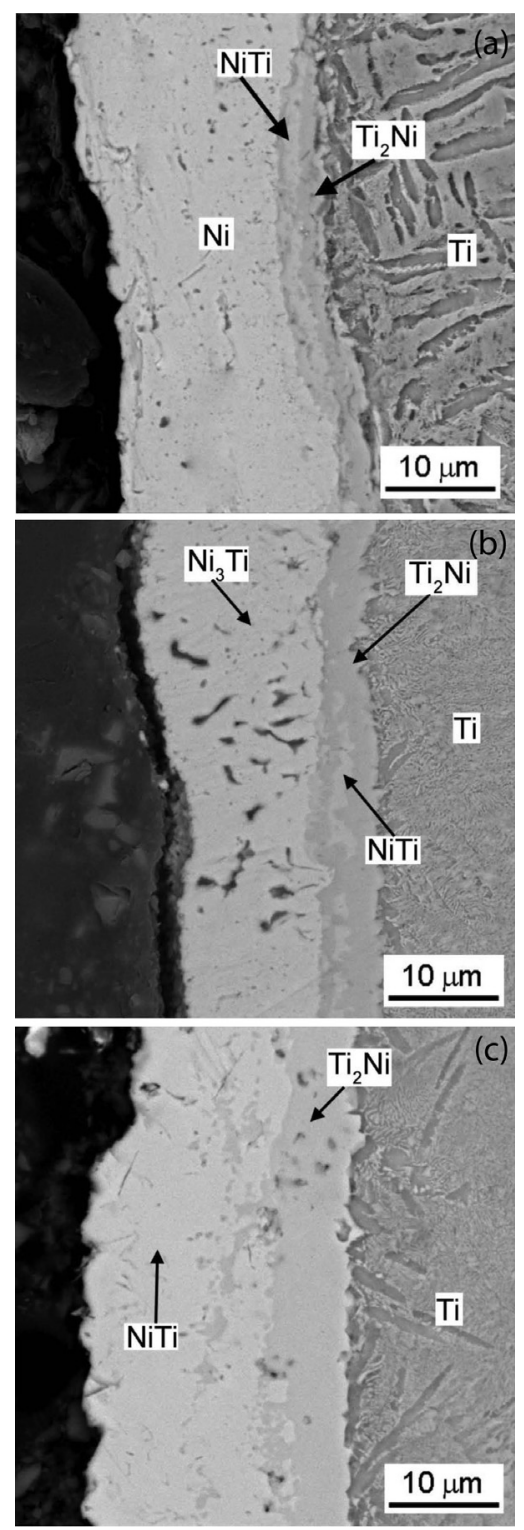

Figure 6: Microstructure of Ni-Ti model samples annealed at $900{ }^{\circ} \mathrm{C}$ for: a) $30 \mathrm{~min}$, b) $60 \mathrm{~min}$ and c) $120 \mathrm{~min}$
$\mathrm{Ni}_{3} \mathrm{Ti}$ layer consumes almost the whole residual thickness of the nickel coating (Figure $\mathbf{6 b}$ ). The $\mathrm{Ni}_{3} \mathrm{Ti}$ layer is very porous, which confirms the previous results, where the $\mathrm{Ni}_{3} \mathrm{Ti}$ phase was found to be a source of porosity. ${ }^{16}$ When continuing the annealing, the $\mathrm{Ni}_{3} \mathrm{Ti}$ phase disappears completely, since it reacts with $\mathrm{Ti}_{2} \mathrm{Ni}$ in order to form a thick layer of NiTi phase (Figure 6c). The experiment was stopped after $120 \mathrm{~min}$, because the whole layer was composed of $\mathrm{NiTi}$ and $\mathrm{Ti}_{2} \mathrm{Ni}$ phases (Figures 6c and 7). Calculated parabolic rate constants (Table 4) show that the formation of NiTi (austenite) and $\mathrm{Ni}_{3} \mathrm{Ti}$ is not diffusion-controlled at $900{ }^{\circ} \mathrm{C}$, because the constants vary strongly with the process duration. It confirms that the process runs in SHS mode.

Table 4: Parabolic rate constant of the formation of $\mathrm{Ti}_{2} \mathrm{Ni}, \mathrm{NiTi}$ and $\mathrm{Ni}_{3} \mathrm{Ti}$ layer vs. annealing duration at $900{ }^{\circ} \mathrm{C}$

\begin{tabular}{|c|c|c|c|}
\hline \multirow{2}{*}{$\begin{array}{c}\text { Annealing } \\
\text { duration } \\
(\mathrm{min})\end{array}$} & \multicolumn{4}{|c|}{$\begin{array}{c}\text { Parabolic rate constant of the growth of } \\
\text { layers }\left(\times 10^{-4} \mu \mathrm{m} \mathrm{s}^{-1}\right)\end{array}$} \\
\cline { 2 - 4 } & $\mathrm{Ti}_{2} \mathrm{Ni}$ & $\mathrm{NiTi}$ & $\mathrm{Ni}_{3} \mathrm{Ti}$ \\
\hline 30 & 16.1 & 46.7 & 0 \\
\hline 60 & 87.1 & 40.1 & 267.0 \\
\hline 120 & 50.0 & 325.0 & 0 \\
\hline
\end{tabular}

To prove the results of the experimental model, the real compressed powder mixtures were prepared and heated at $800{ }^{\circ} \mathrm{C}$ and $900{ }^{\circ} \mathrm{C}$ with a holding time of 120 $\min$. The same heating rate as in the experimental model (approx. $300{ }^{\circ} \mathrm{C} / \mathrm{min}$ ) was applied. The sample prepared by heating at $800{ }^{\circ} \mathrm{C}$ is composed of unreacted nickel and titanium particles covered by layers of $\mathrm{Ti}_{2} \mathrm{Ni}$, NiTi and $\mathrm{Ti}_{3} \mathrm{Ti}$ of very similar thickness like in the model system (Figure 8a). On the other hand, the sample reactively sintered at $900{ }^{\circ} \mathrm{C}$ is comprised of $\mathrm{Ti}_{2} \mathrm{Ni}$ particles in a NiTi matrix. The morphology of the sample changed from cylindrical shape to irregular shape due to partial melting during the process (Figure 9). This indicates that

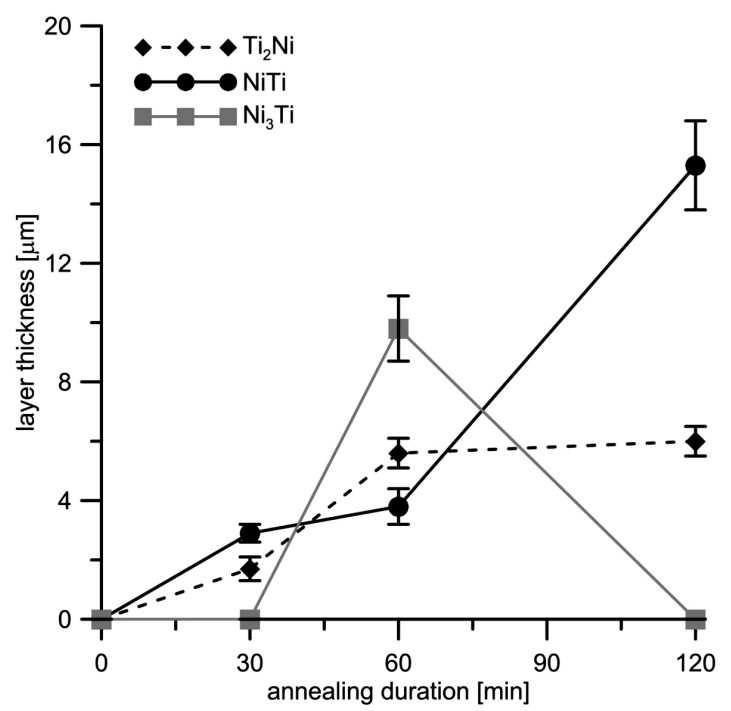

Figure 7: $\mathrm{NiTi}, \mathrm{Ti}_{2} \mathrm{Ni}$ and $\mathrm{Ni}_{3} \mathrm{Ti}$ layer thickness on model samples vs. duration of annealing at $900{ }^{\circ} \mathrm{C}$ 
P. NOVÁK et al.: FORMATION OF Ni-Ti INTERMETALLICS DURING REACTIVE SINTERING AT 800-900 ${ }^{\circ} \mathrm{C}$

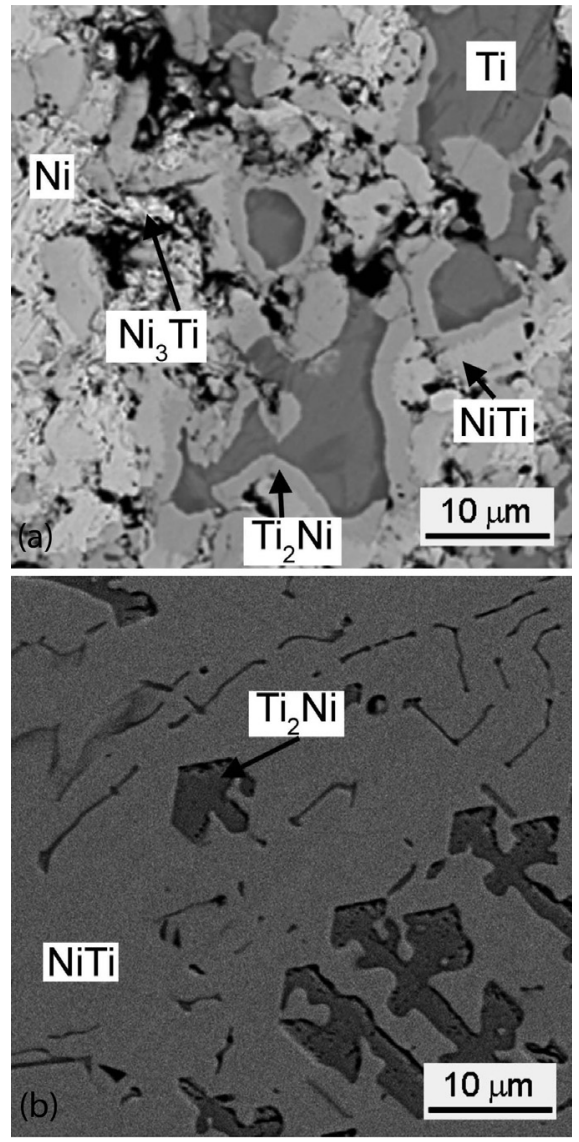

Figure 8: Microstructure of NiTi46 (in mass fractions, $(w / \%)$ ) compressed powder mixtures reactively sintered at: a) $800{ }^{\circ} \mathrm{C}$ for 120 min and b) $900{ }^{\circ} \mathrm{C}$ for $120 \mathrm{~min}$

during annealing of the powder mixture at $900{ }^{\circ} \mathrm{C}$, enormous heat is evolved due to the SHS reaction.

The above-presented results show that the SHS reaction can be initiated immediately after exceeding the $\alpha \rightarrow \beta$ transformation temperature of titanium. It means that it is not necessary to achieve the melt formation by a eutectic reaction at $942{ }^{\circ} \mathrm{C}$. In addition, the rapid SHS process is supported significantly when a high heating

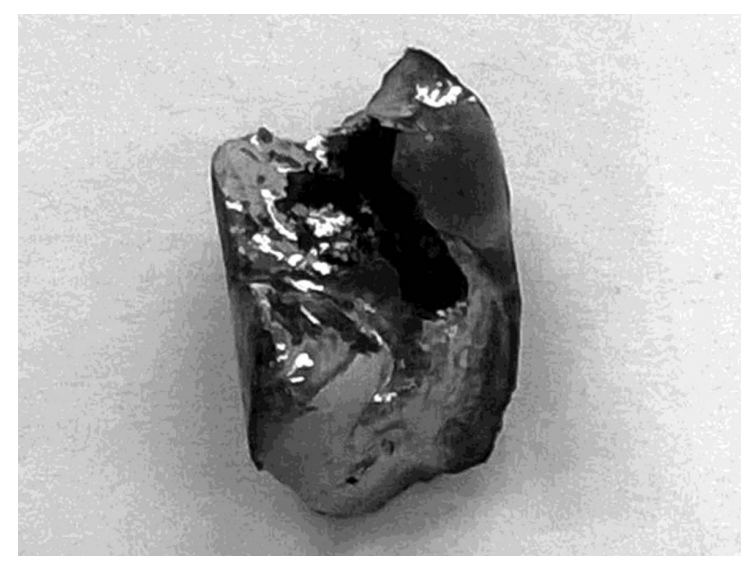

Figure 9: Morphology of NiTi46 (in mass fractions, $(w / \%)$ ) compressed powder mixture reactively sintered $900{ }^{\circ} \mathrm{C}$ for $120 \mathrm{~min}$ rate is applied. ${ }^{17}$ During rapid heating, the diffusion is strongly suppressed. Therefore, the SHS can be initiated by the reaction of solid particles of nickel and titanium, having a cubic structure, producing a mixture of cubic $\mathrm{Ti}_{2} \mathrm{Ni}$ and NiTi phases at the end of the process.

\section{CONCLUSIONS}

In this work the mechanism and kinetics for the formation of $\mathrm{Ni}-\mathrm{Ti}$ phases at $800{ }^{\circ} \mathrm{C}$ and $900{ }^{\circ} \mathrm{C}$ were studied. The results revealed that the rapid SHS reaction is initiated in the solid state by the $\alpha \rightarrow \beta$ phase transformation of titanium. Below this temperature, the growth of Ni-Ti intermetallics is controlled by diffusion of the reactants. Above this temperature, the rapid SHS reaction is initiated. It was proved with an experimental model, where a significant change in the rate constant of the formation of $\mathrm{Ni}-\mathrm{Ti}$ intermetallics was observed at $900{ }^{\circ} \mathrm{C}$, compared with $800{ }^{\circ} \mathrm{C}$. It was confirmed by the change of the slope of the heating curve in thermal analysis, as well as by the in-situ XRD analysis, where a rapid increase of the intensity of the diffraction lines of $\mathrm{Ni}-\mathrm{Ti}$ intermetallics was observed after exceeding approximately $880{ }^{\circ} \mathrm{C}$. The SHS process starts with the formation of $\mathrm{Ni}_{3} \mathrm{Ti}$ phase, which reacts with $\mathrm{Ti}_{2} \mathrm{Ni}$ already present from diffusion stage and forms the NiTi shape-memory phase. The temporary formation of $\mathrm{Ni}_{3} \mathrm{Ti}$ phase results in an increase of the materials' porosity.

\section{Acknowledgement}

This research was financially supported by Czech Science Foundation, project No. 14-03044S. Partial support by COST Action CA15102 is also greatly appreciated.

\section{REFERENCES}

${ }^{1}$ C. M. Wayman, K. Shimizu, The Shape Memory (Marmem), Effect in Alloys, Materials Science and Technology, 6 (1972) 1, 175-183, doi:10.1179/030634572790446028

${ }^{2}$ M. Elahinia, M. Ahmadian, An enhanced SMA phenomenological model. Part I, The shortcomings of the existing models, Smart Materials Structures, 14 (2005) 6, 1297-308, doi:10.1088/09641726/14/6/022

${ }^{3}$ M. H. Elahinia, M. Hashemi, M.Tabesh, S. B. Bhaduri, Manufacturing and processing of NiTi implants: A review, Progress in Materials Science, 57 (2012) 5, 911-946, doi:10.1016/j.pmatsci.2011.11.001

${ }^{4}$ S. A. Thompson, An overview of nickel-titanium alloys used in dentistry, International Endodontic Journal, 33 (2000) 4, 297-310, doi:10.1046/j.1365-2591.2000.00339.x

${ }^{5}$ K. Kanjwal, K. R. Yeasting, C. Baptista, H. Elsamaloty, M. Sheikh, M. Elahinia, W. Anderson, J. D. Maloney, Retro-cardiac esophageal mobility and deflection to prevent thermal injury during atrial fibrillation ablation: an anatomic feasibility study, Journal of Interventional Cardiac Electrophysiology, 30 (2011) 1, 45-53, doi:10.1007/s10840-010-9524-2

${ }^{6}$ M. Elahinia, J. Koo, M. Ahmadian, C. Woolsey, Backstepping control of an SMA-actuated robotic arm, Journal of Vibration and Control, 11 (2005) 3, 407-429, doi:10.1177/1077546305051201 


\section{MATERIALI IN TEHNOLOGIJE/MATERIALS AND TECHNOLOGY (1967-2017) - 50 LET/50 YEARS}

\section{P. NOVÁK et al.: FORMATION OF Ni-Ti INTERMETALLICS DURING REACTIVE SINTERING AT $800-900{ }^{\circ} \mathrm{C}$}

${ }^{7}$ E. Williams, M. Elahinia, An automotive SMA mirror actuator: modeling, design and experimental evaluation, Journal of Intelligent Material Systems and Structures, 19 (2008) 12, 425-1434, doi:10.1177/1045389X07087328

${ }^{8}$ D. Stockel, F. Tinschert, Temperature Compensation with Thermovariable Rate Springs in Automatic Transmissions, SAE Technical Paper Series, (1991), doi:10.4271/910805

${ }^{9}$ R. Venugopalan, C. Trepanier, Assessing the corrosion behaviour of Nitinol for minimally-invasive device design, Minimally Invasive Therapy \& Allied Technologies, 9 (2000) 2, 67-74, doi:10.3109/ 13645700009063052

${ }^{10}$ A. Foroozmehr, A. Kermanpur, F. Ashrafizadeh, Y. Kabiri, Investigating microstructural evolution during homogenization of the equiatomic NiTi shape memory alloy produced by vacuum arc remelting, Materials Science and Engineering, A528 (2011) 27, 7952-7955, doi:10.1016/j.msea.2011.07.024

${ }^{11}$ S. K. Sadrnezhaad, S. B. Raz, Interaction between Refractory Crucible Materials and the Melted NiTi Shape-Memory Alloy, Metallurgical and Materials Transactions B, 36B (2005) 3, 395-403, doi:10.1007/s11663-005-0068-2

${ }^{12}$ https://ec.europa.eu/growth/sectors/raw-materials/specific-interest/ critical_cs

${ }^{13}$ C. B. Wang, S. Zhang, Q. Shen, L. M. Zhang, Investigation on reactive sintering process of boron carbide ceramics by XRD, Materials Science and Technology 25 (2009) 6, 809-812, doi:10.1179/174328408X363371

${ }^{14}$ P. Novák, A. Michalcová, J. Šerák, D. Vojtěch, T. Fabián, S. Randáková, F. Průša, V. Knotek, M. Novák, Preparation of Ti-Al-Si alloys by reactive sintering, Journal of Alloys and Compounds, 470 (2009) 1-2, 123-126, doi:10.1016/j.jallcom.2008.02.046
${ }^{15}$ M. Whitney, S. F. Corbin, R. B. Gorbet, Investigation of the mechanisms of reactive sintering and combustion synthesis of NiTi using differential scanning calorimetry and microstructural analysis, Acta Materialia, 56 (2008) 3, 559-570, doi:10.1016/j.actamat. 2007.10.012

${ }^{16}$ P. Novák, P. Pokorný, V. Vojtěch, A. Knaislová, A. Školáková, J. Čapek, M. Karlík, J. Kopeček, Formation of Ni-Ti intermetallics during reactive sintering at 500-650 ${ }^{\circ} \mathrm{C}$, Materials Chemistry and Physics, 155 (2015), 113-121, doi:10.1016/j.matchemphys.2015. 02.007

${ }^{17}$ P. Novák, L. Mejzlíková, A. Michalcová, J. Čapek, P. Beran, D. Vojtěch, Effect of SHS conditions on microstructure of NiTi shape memory alloy, Intermetallics, 42 (2013), 85-91, doi:10.1016/ j.intermet.2013.05.015

${ }^{18}$ P. Novák, V. Knotek, M. Voděrová, J. Kubásek, J. Šerák, A. Michalcová, D. Vojtěch, Intermediary phases formation in Fe-Al-Si alloys during reactive sintering, Journal of Alloys and Compounds, 497 (2010) 1-2, 90-94, doi:10.1016/j.jallcom.2010.03.028

${ }^{19}$ P. Novák, J. Kubásek, J. Šerák, D. Vojtěch, A. Michalcová, Mechanism and kinetics of the intermediary phase formation in $\mathrm{Ti}-\mathrm{Al}$ and Ti-Al-Si systems during reactive sintering, International Journal of Materials Research, 100 (2009) 3, 353-355, doi:10.3139/146.110028

${ }^{20}$ A. T. Fromhold, Parabolic oxidation of metals, Physics Letters, A, 29 (1969) 3, 157-158, doi:10.1016/0375-9601(69)90088-7

${ }^{21}$ T. B. Massalski, Binary Alloy Phase Diagrams, 1990, ASM, Materials Park 